\title{
PROSPECTS OF THE VITICULTURE DEVELOPMENT IN UZBEKISTAN
}

\author{
Ibragimov Mansur Mardonovich, \\ PhD, Samarkand Institute of Economics and Service.
}

\begin{abstract}
The article describes the existing problems in the development of viticulture and offers scientific and practical recommendations for their solution. At the same time, special attention is paid to the work on more effective use of existing opportunities in the development of viticulture and fruit and vegetable growing in the country, filling the domestic market, increasing export potential.

Keywords - Grapes, Processing, Export, Cluster, Cooperation, Efficiency, Value Chain.
\end{abstract}

\section{INTRODUCTION}

In order to provide the population of the country with food products, to fill the domestic market with quality fruits and vegetables and viticulture, it is important to further develop fruit and vegetable growing and viticulture, which is one of the leading sectors in the agro-industrial complex. Because this sector allows the population to continuously meet the demand for quality food products, and industrial enterprises to raw materials, as well as a source of foreign exchange earnings from the export of products. In addition, Uzbekistan is a country with high potential for horticulture and viticulture.

\section{LITERATURE REVIEW}

The following scholars on the development of viticulture have considered this in their works: Inobatov A. [5], Khasanov S. [6].

\section{RESEARCH METHODOLOGY}

In this research, we used of methods of analysis and synthesis, grouping, comparative and structural analysis, induction and deduction.

\section{ANALYSIS AND RESULTS}

Among the tasks set out in the "Priorities for Economic Development and Liberalization" of the Action Strategy for the five priority areas of development of the Republic of Uzbekistan for 2017-2021, approved by the Decree of the President of the Republic of Uzbekistan dated February 7, 2017 No 4947 "On Action Strategy for further development of the Republic of Uzbekistan" ... to reduce the area under cotton and cereals, to plant potatoes, vegetables, fodder and oilseeds on vacant lands, as well as to further optimize the area under new intensive orchards and vineyards. In particular, in 2017 it is planned to develop high-yielding, early-ripening and sweet-tasting vineyards on the basis of modern agrotechnologies and increase the production of export-oriented products in demand in world markets, including the establishment of 7.3 thousand hectares of vineyards and reconstruction of 9,000 hectares, gradual conversion of existing low-yielding vineyards to $10 \%$ or 14.1 thousand vineyards per year, introduction of drip irrigation system in newly established and existing intensive vineyards, expansion of vineyards and renewal of obsolete and unusable vineyards, vineyards increase in production due to increase in land productivity as a result of modernization.

The head of state and the government have adopted a number of resolutions and decrees on the development of viticulture and fruit and vegetable growing in the country, more efficient use of existing opportunities, filling the domestic market, increasing export potential.

In this regard, in particular, the Decree of the President of the Republic of Uzbekistan dated March 29, 2018 PF-5388 "On additional measures for the accelerated development of fruit and vegetable production in the Republic of Uzbekistan", October 17, 2018 "On additional measures to increase the efficiency of fruit and vegetable exports, Decree No. PQ-4239 of March 14, 2019 "On measures to develop agricultural cooperation in the field of fruit and vegetables", PF-5853 of October 23, 2019 "On approval of the Strategy of agricultural development of the Republic of Uzbekistan for 2020-2030", Resolution No. PQ-3978 of December 11, 2019 "On additional measures for further development of the fruit and vegetable and viticulture sector, the creation of a value chain in the industry" is important for the development of the industry.

In accordance with the Resolution "On measures to develop agricultural cooperation in the field of fruit and vegetables", on the principles of encouraging the creation of value chains in the fruit and vegetable industry, especially in viticulture, ensuring the sustainability of production and export of quality fruits and vegetables, expanding the financial capacity of producers, as well as voluntary and share participation to increase production competitiveness The Institute of Agricultural Associations was established on the basis of cooperative associations of independent and interdependent agricultural enterprises, farms and dehkan farms and landowners. In 2019, a total of 41 agricultural associations were established in 8 districts of Jizzakh, Samarkand, Tashkent and Fergana regions, in 2020 - 31 fruit and vegetable associations in 22 districts of Fergana, Andijan and Namangan regions, in 2021 - another 100. expressions are formed.

The Resolution of the President of the Republic of Uzbekistan dated December 11, 2019 "On further development of the fruit and vegetable and viticulture sector, additional measures to create a value chain in the industry" sets the development of clusters and cooperation in agriculture according to new rules. According to the resolution, the interest rate on loans up to 20 billion soums for the construction of vineyards, storage and processing facilities will be reimbursed 
in excess of the refinancing rate of the Central Bank, but not more than $8 \%$, or a guarantee of $50 \%$ of the loan amount, to allocate loans to banks participating in the financing of intensive horticultural and vineyard projects; to establish a grace period for the main loan before the orchards and vineyards are harvested.

The ongoing economic reforms in the sector to implement these decisions provide an opportunity to address the following socio-economic issues:

- Economically - fruits and vegetables and grapes account for $32.2 \%$ of total agricultural production (8.7\% of GDP) and are one of the main sources of income in rural areas. It has a direct impact on the development of the processing industry. This sector also plays a key role in the country's agricultural exports;

- socially - the sustainable development of fruit and vegetable growing and viticulture, together with the rural population, will have an impact on improving the social welfare of the entire population of the country.

Along with the creation of a legal framework for the development of fruit and viticulture, the organizational measures taken, the benefits provided to the industry, there are some problems that hinder the development of the industry. "... the lack of a systematic system of effective market mechanisms in the industry, especially in the development of fruit and vegetable growing and viticulture, the lack of a scientific approach leads to the underutilization of the existing potential of the industry. According to estimates, there is an opportunity to earn 7 times more from grapes, 6 times more from cherries and 5 times more from walnuts than from raw cotton grown on 1 hectare.

It is also impossible to say that the existing opportunities for processing, storage and export of grapes are being fully used. Today, only $15 \%$ of fruits and vegetables and grapes grown in our country are processed and $8 \%$ are exported.

The analysis shows that the growth of grape production in the country requires a number of problems and shortcomings in the storage and processing of grapes, some changes in the reform of the industry with the widespread use of modern innovative, resource-saving digital technologies.

In our opinion, the following problems limit the opportunities for further development of viticulture, large-scale export of industry products:

- The issues of deep modernization, technical and technological renewal of the viticulture sector in the country have not yet been fully resolved;

- Insufficient use of opportunities to improve the packaging and design of agricultural products;

- the capacity of special refrigerated warehouses for storage of fruit and grape products is not enough to meet the demand;

- The logistics system for long-distance transportation of fruit and grape products is not well established;

- Most farmers do not have the necessary knowledge and skills and reliable information channels on world market prices, conjuncture and competition environment, procedures for export operations, laws and regulations in world markets;

- Consulting and service services, infrastructure to promote the export of agricultural products in the country are underdeveloped.

In-depth scientific study of these problems, finding solutions to them is one of the urgent tasks for the development of the network today.

\section{CONCLUSION/RECOMMENDATIONS}

In our opinion, it is expedient to develop and implement the following measures for further development of viticulture in the country.

1. Increasing the level of mechanization of agro-technical measures in the viticulture sector. Strengthening the material and technical base of farmers specializing in viticulture, allocating low-interest and long-term loans for the purchase of existing special equipment for agricultural machinery, further improving the system of leasing of equipment.

2. Further development of the cluster system in order to increase the interest of grape growers, purchase of grape products grown by them, their export to domestic and foreign markets, as well as the organization of processing and export. To provide the exporter with all-round practical assistance in lending, insurance, positioning in foreign markets, "geographical, economic, financial and quality risks", transport and logistics, obtaining relevant certificates, food safety and standards, participation in international exhibitions and fairs support.

3. Increasing the number of grape processing enterprises of various forms of ownership, eliminating the monopoly in the field of grape processing and strengthening competition. Enhancing the storage and processing of grape products grown on the basis of the development of compact and small branches of grape processing enterprises in the wine-growing regions of the country, as well as the production of competitive finished products in demand in the domestic and foreign markets (currency allocation, tax incentives, loans) etc.).

4. Creating conditions for direct grape growers to store grapes. At present, the level of refrigeration for storage of fruits, vegetables and grapes in the regions is 3.7\%. Allocation of soft loans for the construction of small-scale storage of grapes, purchase of refrigeration and other storage equipment to meet the needs of farmers and private farms.

5. Establishment of multidisciplinary agro-logistics complexes "Agropark" and "Agrosanoat" based on digital innovative technologies in all convenient locations. In this complex, the creation of a system of all processes from product storage, processing, packaging, sales, biolaboratory service, standardization and export. 
The implementation of these measures will be an important factor in the development of the viticulture sector, increasing the volume of viticulture, expanding the geography of exports and, consequently, increasing the efficiency of the sector.

\section{REFERENCES}

[1] Resolution of the President of the Republic of Uzbekistan dated April 12, 2016 "On measures to improve the system of procurement and use of fruits, vegetables, potatoes and melons";

[2] Decree of the President of the Republic of Uzbekistan dated March 29, 2018 "On additional measures for the accelerated development of fruit and vegetable growing in the Republic of Uzbekistan";

[3] Resolution of the President of the Republic of Uzbekistan dated March 14, 2019 "On measures to develop agricultural cooperation in the field of fruit and vegetables";

[4] Resolution of the President of the Republic of Uzbekistan dated December 11, 2019 "On additional measures for further development of the fruit and vegetable and viticulture sector, the creation of a value chain in the industry";

[5] Inobatov A. Economic bases of development of viticulture in Uzbekistan // Biznes-daily.uz 11.11.2019;

[6] Khasanov S. Trends and prospects for the development of fruit and vegetable growing in Uzbekistan // Magazine "Economic Review" 2020, No. 6 (246);

[7] agrobisiness.ru;

[8] uzexport.com;

[9] stat.uz;

[10] uzex.com. 